\title{
"WIINGE CHI-BAAPINIZI GENIIN ODE: IT REALLY MAKES MY HEART LAUGH": LANGUAGE, CULTURE, IDENTITY, AND URBAN LANGUAGE REVITALIZATION
}

\author{
Lindsay A. Morcom ${ }^{1}$ \\ Queen's University
}

\begin{abstract}
In Canada, the majority of Indigenous people live off-reserve in urban centres. Living offreserve is a risk factor for language loss, as indicated by the fact that 44.9 percent of First Nations people on-reserve are able to conduct a conversation in an Aboriginal language, compared to only 13.4 percent of First Nations people off-reserve (Statistics Canada, 2019). For this reason, urban language revitalization is vital, yet it remains understudied and underfunded (Ball \& McIvor, 2013; Chao \& Waller, 2017; Jewell, 2016). The Kingston Indigenous Languages Nest (KILN) is an example of grassroots urban language revitalization. KILN presents Indigenous families in Kingston, Ontario, with opportunities to access language and culture through weekend family-focused sessions, as well as immersion weekends, evening adult language classes, digital resource development, and community partnerships focused primarily on Anishinaabemowin, Kanien'kéha, and Cree. Using qualitative data collected through talking circles, I explore what effect the weekend sessions have on participants' lives. The results indicate that participation improves language use. However, its impact stretches beyond this; participants describe a deepening of their cultural understanding and connection to community as key parts of the development of their identities as urban Indigenous people. It is clear that culture-based pedagogy is central to both language survivance and cultural and identity growth. It deepens participants' understanding of themselves as urban Indigenous people, allows them to experience their culture as a way of life, creates new understandings of Indigenous identity and community, and validates their community identity as equal to other Indigenous ways of being.
\end{abstract}

Keywords: language revitalization, urban, culture, community, identity

Citation: Morcom, L. (2021). "Wiinge chi-baapinizi geniin ode: It really makes my heart laugh": Language, culture, identity, and urban language revitalization. WINHEC: International Journal of Indigenous Education Scholarship, 16(1), pp. 179-209. http://dx.doi.org/10.18357/wj1202120286. Special Issue on Indigenous Language Revitalization: Innovation, Reflection and Future Directions, Guest Co-Editors Drs. Onowa McIvor and Kari A. B. Chew.

${ }^{1}$ Correspondence: Lindsay Morcom, Queen’s University, mailto:morcoml@queensu.ca 


\section{Introduction}

In the study of Indigenous language revitalization and education in North America, the emphasis of research tends to be on the education of First Nations children on-reserve or Inuit children living within Inuit Nunangat. On-reserve First Nations communities and communities in Inuit Nunangat are the epicenter for this type of language revitalization work because languages and cultures on-reserve are more present and more homogenous in most cases, providing a speaker community that can maintain and use the language (Statistics Canada, 2019). Furthermore, First Nations and Inuit are increasingly claiming selfdetermination in education and creating language programs and culture-based curricula that are heritage-language specific and appropriate to learners in their communities (Assembly of First Nations [AFN], 2010; Inuit Tapiriit Kanatami [ITK], 2017). This approach is very effective; while $10.7 \%$ of First Nations children (0-14) and $12.2 \%$ of young adults (15-24) report having an Indigenous language as their mother tongue, a higher number, 15.8\% and $16.5 \%$ respectively, can conduct a conversation in one, indicating that First Nations people are effectively learning Indigenous languages as second languages. Similarly, 55.8\% of Inuit children and $57.0 \%$ of young adults have an Inuit language as a mother tongue, while $65.2 \%$ and $64.4 \%$ can conduct a conversation in one.

However, programs and curricula delivered on-reserve or within Inuit Nunangat do not directly serve the majority of the Indigenous population, since more than $70 \%$ of Indigenous people live off-reserve (Congress of Aboriginal Peoples [CAP], 2018). Currently, 44.9\% of First Nations people living on-reserve can conduct a conversation in an Indigenous language, while only $13.4 \%$ living off-reserve are able to do so (Statistics Canada, 2019). This divide is 
even more pronounced within Inuit communities; 64\% of Inuit in Inuit Nunangat speak an Inuit language, but only $10.9 \%$ of Inuit living elsewhere do (Statistics Canada, 2019). Therefore, living off-reserve or outside Inuit Nunangat presents a significant risk factor for language loss.

In the provincially-run public and Catholic schools that today serve the majority of the urban Indigenous population, there is seldom any opportunity to learn an Indigenous language, and so most modern schools continue to participate in what Ball and McIvor (2013) describe as "linguistic genocide" (p. 22). However, Indigenous people in urban centres have as much right as any other Indigenous people to learn their languages and cultures. Inherent and treaty rights are not relinquished when Indigenous people leave their First Nations or other land bases and failing to provide adequate support for Indigenous languages in urban and nonurban contexts is a breach of the federal government's fiduciary duty to Indigenous peoples (Haque \& Patrick, 2015).

Given that urban Indigenous people, communities, and rights are often ignored, urban language revitalization tends to be understudied and underfunded (Baloy, 2011; Ball \& McIvor, 2013; Chao \& Waller, 2017; Jewell, 2016). However, since an increasing number of Indigenous people live in urban centres, which presents a higher risk of language loss, urban language revitalization is essential. In spite of a lack of support, urban Indigenous language revitalization initiatives are happening around the globe and throughout Canada. These efforts demonstrate significant positive effects on language use and language revitalization, 
as well as the cultural connectedness and strength of identity of the people who participate in them.

\section{Purpose}

This article aims to contribute to our understanding of the effects of grassroots urban language revitalization through the perspectives of participants in the Kingston Indigenous Languages Nest (KILN) in Kingston, Ontario, Canada. Through this research, we found that access to language learning through initiatives like KILN strengthens urban Indigenous peoples' language knowledge and enhances language presence within the community by increasing speaker numbers and creating new domains of language use. Within the community, this results in the development of a more positive language ideology. Furthermore, we found that participation in KILN enhanced participants' access to and ability to live their cultures and spiritualities, and it contributed to their sense of identity and belonging. That involved strengthening participants' connections to their heritage Nations, as well as developing a sense of urban identity that prizes diversity and celebrates new ways of living as Indigenous people. Since a growing number of Indigenous people in Canada live in urban centres, it is vital that we understand what the effects of urban language revitalization are, how it enhances the vitality of Indigenous languages, and how individual participants and communities benefit from it. This will help us to ensure that urban Indigenous people have access to the languages that are their birthright and that Indigenous languages and people continue to thrive both on- and off-reserve. 


\section{Contexts and Results of Urban Language Revitalization}

Existing studies of urban language revitalization reveal that these efforts are beneficial to Indigenous languages in a variety of ways (Baloy, 2011; Davis, 2015; Jewell, 2016; Morgan \& Clarke, 2011; Pitawanakwat, 2009; Sarivaara et al., 2013; Sherry-Kirk, 2014; Shulist, 2017). Most obviously, these programs have the potential to increase speaker numbers and expand domains of language use (Sarivaara et al., 2013). They also expand the potential for community and intergenerational transmission (Davis, 2015; Jewell, 2016), and they give insight into innovative practices that are connected to urban contexts. These include developing vocabulary for urban lifestyles; creating and developing practices that enable second language learners to effectively lead revitalization where there are fewer fluent speakers; and creating space, both metaphorically and physically, for language learning, teaching, and use that is practical and relevant for urban people (Baloy, 2011; Jewell, 2016, Pitawanakwat, 2009).

Furthermore, urban language revitalization presents an opportunity to (re)develop the language ideologies of urban Indigenous communities and sometimes also of coexisting nonIndigenous urban communities. Language ideologies are the beliefs and attitudes speakers hold about language, which are linked to larger social and cultural systems (Shulist, 2017). Increased access to Indigenous languages demystifies them and encourages community members to understand their value in terms of positive factors such as connections to culture and spirituality, stronger identity, belonging and community, and resistance to assimilation (Dementi-Leonard \& Gilmore, 2015; Haque \& Patrick, 2015). It also leads them to question 
the idea that language knowledge is only useful if it results in increased economic advantage, which legitimizes underfunding (Haque \& Patrick, 2015) .

Because of the complex connections between language and other facets of life, urban language revitalization efforts have implications beyond language survivance. With language comes an increased understanding of Indigenous cultures (Norton \& Toohey, 2011; Sarivaara et al., 2013). Language learning opportunities often present access, sometimes for the first time, to traditional foods and activities (McIvor et al., 2009), as well as deeper aspects of Indigenous cultures, philosophies, and worldviews. Through language, learners learn about themselves, strengthen their identities, and express pride in their culture, which creates a "feedback loop" that makes them more likely to engage in cultural activities and even become culture keepers (Fast, 2014; Luning \& Yamauchi, 2010). Language reclamation is for many a profoundly spiritual undertaking (Baloy, 2011). Indigenous languages offer access to practical elements of spirituality such as prayers, songs, and ceremonies (McIvor et al., 2009). On a deeper level, connecting to Indigenous languages strengthens Indigenous people's connection to their/our communities, ancestors, philosophies, land, and Creator and makes us aware of our responsibilities to pass on our collective knowledge (Dementi-Leonard \& Gilmore, 1999; Fast, 2013; McIvor et al., 2009). Culture and spirituality are significant protective factors for at-risk communities and help to disrupt patterns of suicide, substance misuse, and other effects of intergenerational trauma that are present in many Indigenous communities (Ball \& McIvor, 2013; Baloy, 2011; Fast, 2014; McIvor et al. 2009; Sherry-Kirk, 2014). 
Language, culture, and spirituality are some of the most tangible markers of culture and group identity, and they are also central to cultural transmission (De Souza \& Rymarz, 2007; McIvor et al., 2009; Norton \& Toohey, 2011). Language is particularly significant to identity because it is not only a way to understand Indigenous identity; it is a way to openly claim and visibly enact it. This is often fraught with anxiety as learners begin their language journey, but becomes profoundly validating as they continue, especially when they are met with encouragement and acceptance from other learners, speakers, and Elders (King \& Hermes, 2014). Language revitalization and its connection to identity are important for both past and future generations. In many cases where older people have been shamed for language, culture, and Indigenous identity, younger people may experience shame for not being more linguistically and culturally connected (Fast, 2014; King \& Hermes, 2014; Sherry-Kirk, 2014). As members of different generations overcome shame and engage in language and culture revitalization, culture and pride in Indigenous identity may flow back to older generations as well as forward to younger ones (De Souza \& Rymarz, 2007; Luning \& Yamauchi, 2010).

There is frequently a misapprehension that urban life is incompatible with Indigenous identity (De Souza \& Rymarz, 2007; Sherry-Kirk, 2014; Shulist, 2018). In urban contexts, pressure to assimilate may be greater, there may be a more significant divide between Indigenous and non-Indigenous cultures, and Indigenous people may experience social, spiritual, and cultural isolation (De Souza \& Rymarz, 2007). Additionally, more people may be navigating the complexities of mixed or multiple Indigenous, settler, and immigrant heritages (Baloy, 2011; Lawrence, 2004). Access to language and culture reinforces ties to land and connects those who have recently moved from elsewhere and those who have lived 
locally for some time, thereby strengthening community members' connections to their heritage cultures, languages, territories, and Nations (Baloy, 2011; De Souza \& Rymarz, 2007; Fast, 2014; Sarivaara et al., 2013; Shulist, 2018). At the same time, it also presents an opportunity to imagine new ways of being Indigenous and creating a unique urban Indigenous identity (Andersen, 2013; Davis, 2015; Norton \& Toohey, 2011). In creating opportunities to come together through language and culture, urban Indigenous people redevelop their own sense of Indigeneity, help one another to overcome shame and fear surrounding "enoughness," and develop their own unique community, with its own teachings, practices, and traditions (Shulist, 2018). Those practices and ways of being are equally valid expressions of Indigeneity to those found in on-reserve, rural, or northern spaces.

\section{Context of KILN and This Study}

KILN is centred in Kingston, Ontario, Canada, and includes members of the local urban community as well as people from surrounding rural areas. Kingston is a fairly small city, with a population of approximately 117,660 (Statistics Canada, 2018). It is situated on the north shore of Lake Ontario at the mouth of the St. Lawrence River, approximately halfway between Toronto $(260 \mathrm{~km})$ and Montreal $(280 \mathrm{~km})$, and southwest of Ottawa and the National Capital Region (175km). Overall, the residents of Kingston are primarily of European settler heritage (74-82\%), and the vast majority of people, 94\%, speak English at home (Statistics Canada, 2018). Kingston is steeped in settler colonial history, having been the capital of the Province of Canada from 1841-1843 (Osborne, 2019), which heavily informs local mainstream culture and urban conceptualization. People who identify as Indigenous 
comprise $3.7 \%$ of the population, and only $0.06 \%$ of people (or $1.6 \%$ of the Indigenous population) speak an Indigenous language (Statistics Canada, 2018).

The most prominent Indigenous Nations in Kingston are Anishinaabe, Kanien'kehá:ka (Mohawk) and other Nations of the Haudenosaunee confederacy, and Cree. These communities belong to unrelated language families, as Anishinaabemowin and Cree are Algonquian and Kanien:kéha is Iroquoian. The land where the city of Kingston is situated is traditionally considered shared Anishinaabe and Haudenosaunee territory and is governed historically and today by the Dish with One Spoon Wampum. The nearest First Nations Reserve is Tyendinaga Mohawk Territory $(60 \mathrm{~km})$. Alderville First Nation is $150 \mathrm{~km}$ from Kingston and is home to Mississauga Anishinaabe people who historically occupied the Kingston region and were displaced through colonization (Alderville First Nation, 2016). There are also several Algonquin non-Indian Act communities in the region including Ardoch Algonquin First Nation (Ardoch Algonquin First Nation, n.d.), Snimikobi First Nation, and Shabot Obaadjiwan First Nation (Algonquins of Ontario, 2013); these communities are without reserves at the time of writing but the latter two are currently involved in the Algonquins of Ontario Land Claim Negotiations, which includes lands bordering Kingston (Algonquins of Ontario, 2013; Lawrence, 2004). The Cree community in the city has developed due to several factors, particularly a partnership between Kingston Health Sciences Centre (KHSC) and the Weeneebayko Area Health Authority, which serves communities in Western James Bay (KHSC, 2021). The Métis community locally is served by the Highland Waters Métis Council of the Métis Nation of Ontario (Métis Nation of Ontario 
[MNO], 2021). Kingston is also home to several colleges, universities, healthcare facilities, and correctional facilities, which has added to the diversity of the Indigenous community.

\section{History and Development of KILN}

KILN began in 2014 when a few local people began gathering informally to deepen their knowledge of their heritage languages. It became apparent through these meetings that there was a wide desire locally for access to language. KILN originally sought to present opportunities for Indigenous children to learn language and culture through biweekly musicbased language learning activities. Many families attended sessions regularly, and many adults without children attended as well. Since then, KILN has maintained its bi-weekly sessions but has expanded to include land education; language and culture immersion weekends; community-based Anishinaabemowin language lessons at the beginner and intermediate levels; cooking lessons focused on natural foods; digital resource development for Anishinaabemowin, Kanien'kéha, and Cree; and partnerships with community organizations, school boards, libraries, and Queen's University. The membership of KILN is diverse and has included people who are Anishinaabek (primarily Ojibwe and Algonquin), Haudenosaunee (primarily Kanien’kehá:ka), Métis, Cree, Oji-Cree, Carrier, Mi'kmaq, Lakota and more, as well as settler allies (KILN, 2019). The organization's programming has generally focused on Anishinaabemowin and Kanien'kéha and, to a lesser extent, Cree. There have also been events for Mi'kmaq and Lakota (KILN, 2019). 


\section{Positionality}

Wiikwedongkwe ndizhinikaaz. Makwa ndoodem. Wenji-maajijiwang gichigami-ziibi ndoonjibaa. Ardoch Algonquin First Nation ndibendaagoz. My Anishinaabe name means "Woman in the Bay," and I am a member of the Bear Clan. I live at the headwaters of the St. Lawrence River (Kingston, Ontario). I am member of Ardoch Algonquin First Nation, and I am also a member of and accountable to the urban Indigenous community in Kingston. In addition to my Algonquin heritage, I carry French Canadian and Black Sea German heritage. I was one of several community members involved in founding KILN under the leadership of Maureen Buchanan, who was and is still the driving force behind much of the language revitalization work done locally. I am aware that as a community member and founding member of KILN, I approach this research with a longstanding connection to most participants, a love for the community and the organization, and an assumption that the work of KILN is a positive contribution to our community. I have done my best to see past my assumptions and biases and listen deeply to the voices of those who shared their thoughts with me, and I am hopeful that my knowledge of KILN and my love for and accountability to my urban community will allow me to present this research in a way that properly represents them.

\section{Methodology}

This a Community-Based Participatory Action Research (CBPAR) study that evolved out of discussions with KILN founders as part of development and expansion planning. In 2016, KILN was branching beyond its bi-weekly sessions to include other community activities and partnerships, and we wished to know why participants attended KILN sessions, what impact 
KILN had on individuals and the community, and what participants hoped to see going forward. In June 2016, four questions were developed in collaboration with KILN organizers and Elders. These questions pertained only to the bi-weekly play-based language learning sessions. They were

1) Why do you come to the language nest?

2) Do you feel that the language nest has helped your language knowledge? How?

3) Do you feel that the language nest has helped you grow in your Indigenous identity or helped you grow as an ally to Indigenous people? How?

4) What do you think works best at the language nest? What would you like to see in the language nest to make it better?

Prior to being conducted, the study was granted ethics approval by the General Research Ethics Board of Queen's University, and fellow KILN leadership also expressed their support. During the study, 15 participants took part in two talking circles. The participants were of Anishinaabe, Haudenosaunee, Cree, Métis, Mi'kmaq, and non-Indigenous heritages. Since I am focusing on Indigenous identity-building, for the purposes of this article the voices of Indigenous participants have been privileged. Each talking circle was four rounds long, corresponding to local ceremonial protocols, and each of the questions was the basis for a round. The talking circles were held according to both Anishinaabe and Haudenosaunee protocols. Before each circle, participants were offered the opportunity to smudge. ${ }^{2} \mathrm{~A}$ talking stick and a digital recorder were passed to the right for one talking circle in Haudenosaunee

\footnotetext{
${ }^{2}$ Smudging is a spiritual ceremony involving the burning of sacred medicines, in this case sage, and the wafting of smoke over oneself, someone else, or an object or space to cleanse, heal, and centre us.
} 
tradition, and to the left for the other in Anishinaabe tradition. Responses were given mostly in English, with some Anishinaabemowin and Kanien'kéha words and phrases, which I checked with more fluent speakers for accuracy or transcription, although I did not correct learner errors. I transcribed and manually coded the recordings for themes and quantified recurrences, reviewing the data on three occasions several months apart and prior to a full review of literature; this was to ensure that coding was as representative as possible of what participants had shared and to help avoid bias in my analysis. For the purpose of privacy, all data have been anonymized, but I have included direct quotes to help convey participants' authentic voices. Before dissemination anywhere else, a written report was prepared and given to KILN organizers and any participants who wished to read it. Kingston Indigenous Language Nest's leadership have also read this paper prior to submission and publication. ${ }^{3}$

\section{Analysis}

Upon coding, several salient themes emerged from the data. These themes were language, culture, identity, community, land, diversity, and decolonization. This paper will deal primarily with the more individual aspects of language, culture, and identity. Although there is some overlap, the more collective themes of community, land, diversity, and decolonization will be addressed in a separate publication.

\footnotetext{
${ }^{3}$ I am grateful to KILN leaders Deb St. Amant and Maureen Buchanan for their helpful review and feedback on this paper. Chi-miigwech.
} 


\section{Language}

Unsurprisingly, "language" was by far the most salient code, with 51 recurrences. Within this theme, numerous subthemes emerged. Responses differed depending on whether participants were first or second language speakers, learners with some prior knowledge, or beginners. More fluent participants talked about KILN sessions as opportunities to speak their language, remember things they had forgotten, and stop themselves from losing it due to lack of practice. In this way, for fluent people, the sessions "gift the language back." As one participant said,

Coming to this [KILN] actually creates a challenge for me, and it's a good challenge because when I go home I feel real productive like I've done something worthwhile and practiced. . . .If you don't practice you lose it real fast so I appreciate these opportunities and a friendly reminder of what's important.

Similarly, more advanced second language speakers talked about having a chance to both repeat what they already knew and develop new knowledge and understanding. Speakers who arrived with very little or no language knowledge said that developing a base of even a few words helped connect them to their cultures, communities, and families:

I had no knowledge, just a few words or a few statements before coming to the language nest. And now I'm at a point where I can sing songs with my children, I can tell them to do something in Mohawk and use like small commands and things like that, and ... that's huge for me.

Many participants noted that having learners at all levels, especially fluent speakers, made a big difference in their learning. Since there are few fluent speakers in Kingston, both fluent 
and non-fluent participants spoke about how they value the opportunity to learn from more fluent people and to share what they know.

The intergenerational attendance at KILN sessions was valuable to the participants. While they would have liked more teenagers to attend, having people of multiple generations, from infants to older people, was a benefit because it allowed for the creation of a safe environment where adults could learn alongside children and where children could be free to engage in their own activities and participate as they wanted to without pressure. Some participants said that even when it looked as though their children were not paying attention, they would repeat or ask about things they had learned after the sessions. In some cases, children who attended sessions were learning their language elsewhere, and were able to teach it back to adult attendees. As one participant whose younger family members learn their language in school, something she did not have the opportunity to do, said,

Sometimes when I listen though I can kind of pick up what people are talking about. But it's the grandchildren ... and the children that are going to be making a full circle with that. And so the language nest is a good thing. Because sometimes we learn from our kids.

The pedagogy of the KILN sessions, which was modelled on language learning approaches for young children, was central to the non-threatening, multi-generational environment. The pedagogy was engaging, play-based, and multi-modal, which allowed learners to identify and work with their personal strengths and weaknesses and to learn through various approaches. As one speaker said, "one of the things that we do really well here is incorporating the 
auditory, the visual, and the kinesthetic learning. To be able to hear, to be able to see, and to be able to experience the language I think is really important." Participants felt safe to ask questions and make mistakes, and they encouraged one another. This empowered all the participants to expand on their learning: "I think that it has ... emboldened me to speak, emboldened me to learn, emboldened me to try and embrace all of myself, all of myself. Here, at present." Their experience kindled a love of Indigenous languages more generally in participants, which was fuelled by having access to both Anishinaabemowin and Kanien'kéha: "Really, I love any opportunity to learn the language, both languages. I love them." It also gave them the chance to celebrate the vibrance and resilience of their languages: "When you come here to speak the language, the language is not dead, it's alive, and it makes your heart laugh with joy that you can hear the language, and be in the language, and share the language."

Beyond the sessions, participants talked about KILN as a motivator for language learning and use in their daily lives. They were inspired by one another because they saw progress in each other and were mutually supportive as like-minded language learners. They also felt accountable to one another to remember what they had learned at sessions, to keep developing on their own, and to make sure their commitment to language was not put aside because of other priorities in their lives. As one participant said,

The nest structure and the nest commitment kind of gives you some structure or some impetus to keep going. You're kind of semi-accountable to other people to remember what was done and continue and learn the next thing, as opposed to if you're on your 
own you might say, "oh well I can do that next week, I'm really busy." It gives you some structure to keep pushing ahead.

Access to ideas and resources enabled participants to expand domains of language use to their home and personal lives. Participation also taught or reminded participants that language is central to culture and worldview and enabled them to develop deeper understanding of cultural concepts that do not translate well into English.

\section{Culture}

The participants recognized language and culture as inextricably related, and so culture was highly salient with 16 recurrences. They spoke about how creating space for language has deepened their relationships to their cultures and allowed them to access cultural knowledge that had been forgotten or lost to them and their families. They found KILN sessions to be a place not only to learn about Indigenous cultures, but to live them. They appreciated the ability to share what they knew and learn from others in a spirit of equality with people from their own and other Nations. One participant described KILN as "so many different tribes learning from each other and sharing with each other in peace like the Creator meant us." They also valued the opportunity to experience Indigenous ways of teaching and learning, particularly in ways that honoured children and decentred adults. One participant pointed out that the cultural knowledge that the children were acquiring through participation would be central to their resilience as they grew:

Somebody said to me that love and support and guidance actually aren't enough—that culture is really important for raising children, and I can really understand that 
because when you've faced racism in your life if you have your culture behind you, you'll be able to withstand, and recover, and be resilient much better.

Within the theme of culture, the sub-theme of spirituality stood out, with six recurrences. The sessions have always involved Indigenous spiritual practices and teachings and have always been done with respect for Indigenous cultural protocols. For some, particularly those who had been raised as Christians, this presented an opportunity to think about how they could decolonize or recontextualize their beliefs. For others, it reawakened Indigenous teachings they had forgotten and gave them a chance to share spiritual knowledge. Several observed that KILN did not just perform Indigenous spirituality, it meaningfully practiced it. Examples they gave included honouring the equality of participants; connecting to holistic wellness based in traditional medicines, teachings and foods; and reminding participants of their connections to the land and their other-than-human relations.

\section{Identity}

For the participants, cultural and linguistic development was linked to identity, and so identity was also a salient theme with 13 recurrences. Many KILN participants are Indigenous people of mixed heritage, and many are separated from what is viewed as typical Indigenous life through urban dwelling. As Lawrence (2004), Peters and Andersen (2013), and Shulist (2018) point out, these factors often result in feelings of not-enoughness. Participants spoke of this frequently. Some talked about accepting who they fully were, sometimes for the first time. As one mixed-heritage participant said of their Indigenous heritage, 
I didn't realize that it meant something. And I was just trying to push it back and push it back, and it didn't do me any good, because all it was doing was making me more frustrated about where I actually belonged.

Others talked about overcoming shame that had led to keeping their heritage a secret, refusing to allow others to dictate who they should be, and the ultimate joy of celebrating the fullness of their heritage; they talked about this in terms of an "awakening of spirit," and spoke about how it allowed them to claim their mixed heritage and their Indigeneity as gifts. They questioned colonial concepts like blood quantum in favour of Indigenous concepts of belonging based in responsibility, recognition, and community orientation. When they were met with community acceptance, it instilled confidence, self-esteem, and a desire to live up to who they fully were as individuals and community members. Connecting to language meant connecting to culture, ancestors, family, and land, which was deeply validating:

There was this connecting that was about language, that was about culture, about family, about finding a place to be valid as a Native person. Like, deeply valid. Not an object, not something, but real. To be seen in a real way.

The acceptance they experienced, along with deepened cultural knowledge, created a deep sense of belonging that informed participants' identities. For many participants, KILN was one, and sometimes the only, place where they could be their full authentic selves: "You know as Indigenous people we have an Indigenous way of thinking, and Indigenous way of being, and the nest is giving that a safe place to be and nurture and springboard from." From a language perspective, the sense of community created safety and removed barriers to language learning. It created pride and understanding as participants got to teach and learn about their own and each other's cultures. Because of its inclusion of ceremony and 
traditional ways of living and its focus on mino-bimaadiziwin, "a good life," KILN also created a positive social space away from influences such as drugs and alcohol, where participants could see Indigenous cultures as pathways toward healthy living and where they could grow in healthy teachings to pass on to younger generations. As mentioned previously, they also felt that the cultural knowledge their children were learning would help them to be resilient against the racism and attempted assimilation they experience as urban Indigenous people.

Participants' diverse identities informed both the conduct of sessions and the development of an urban Indigenous identity:

We don't have that one common language and one common cultural identity. And so we all get to share snippets and pieces of where we come from. And it's that openness that really helps to build our identity and our confidence as a people here in community.... So I think it's really critical to who we are as people.

They saw diversity as a strength for language learning and for community identity-building. For more fluent speakers, it offered the opportunity to be challenged with something new, to compare languages and knowledge systems, and to identify cognates between related languages. From a pedagogical perspective, because they were learning multiple languages, everyone was a learner at some point. That made it more comfortable for them to try new things and make mistakes: "I think it's very interesting to me to have multiple languages in this group because ... everybody can kind of be brave in the group and just make mistakes and try it out." Other participants noted that the respect for cultural diversity in the group also led to respect for individual diversity. They felt that the KILN community valued 
individual identities, preferences, and abilities and enabled members to apply their gifts in ways that would benefit the group:

There's a lot of individual healing going on but there's community building and setting an example and coordinating our efforts and supporting each other.... And getting to understand each other and tap into hidden strengths or hidden talents and supporting certain weaknesses and vulnerabilities and lift each other up.

\section{Discussion}

The participants' perspectives echo the findings of previous research and build on previous knowledge of the importance of urban language revitalization and its influence on the development of urban Indigenous identity.

\section{Language}

Previous research indicates that a primary benefit of urban language revitalization is in increasing speaker numbers and domains of language use (Baloy, 2011; Davis, 2015; Jewell, 2016; Morgan \& Clarke, 2011; Pitawanakwat, 2009; Sarivaara et al., 2013; Sherry-Kirk, 2014; Shulist, 2017). With respect to language, KILN bi-weekly sessions increased speaker numbers within the community. Participants who were more fluent noted that they improved or regained fluency. While non-fluent participants did not achieve fluency, they noted an increase in their language knowledge. The format of the sessions created both metaphorical and physical space for language (Baloy, 2011). Because participants had greater exposure to language and perceived accountability to one another to use the language and gain more knowledge, participation created space in their lives for language. Because 
this is a grassroots initiative and not attached to an institution, the physical space overlapped with public spaces used by other individuals and communities. Most KILN activities have been held at the Kingston Community Health Centre (KCHC), but other public spaces, such as conservation areas, have also been used. This has created new domains of language use within the community, and it has also increased the visibility of Indigenous languages in the wider community (Baloy, 2011; Davis, 2015; Jewell, 2016).

As Morgan and Clarke (2011) and Sherry-Kirk (2014) point out, grassroots community initiatives such as this present opportunities and challenges for language revitalization, and understanding of these contributes to the wider language revitalization movement (Baloy, 2011, Morgan \& Clarke, 2011; Pitawanakwat, 2009; Sherry-Kirk, 2014). As in other research, the communality and welcoming nature of the group encouraged belonging, group contribution, honouring of individual gifts and cultural diversity, and self-direction (Jewell, 2016; Morgan \& Clarke, 2011; Sherry-Kirk, 2014). Since leadership is local, the culture-based pedagogies employed are reflective of the community, its connection to shared Haudenosaunee and Anishinaabe territory, and the diversity of its wider make-up. The lack of firm student-teacher boundaries put everyone into a position of bringing knowledge; fluent speakers noted that this allowed them to grow in language knowledge by teaching, and less fluent participants spoke about the accountability to the community they felt to improve and contribute. Since some of the more fluent participants were younger, and participants came from different language communities, the flow of knowledge was intergenerational, across fluency levels and Nations, which is respectful of Indigenous pedagogies in which everyone is seen has having something to offer (Battiste, 2013). Most of the leadership is 
done by second language speakers, which has doubtlessly resulted in language and culture shifts (Pitawanakwat, 2009). While there is a risk that participants will learn the language incorrectly, the language and culture change that has occurred could also be argued to offer some benefit; the community has created ways of speaking that are unique and cultural understandings that reflect their own community.

As in other studies, the participants' responses reflected the development of positive language ideologies within the community (Davis, 2015; King \& Hermes, 2014; Shulist, 2017, 2018). Participants noted more use of their languages at home and in other social domains, emphasizing their belief that their languages belong in the city. They had also come to understand diversity as additive and the presentation of multiple languages as complementary within their community. On an individual level, they arrived at a greater understanding of their own self-efficacy in language learning; the validation they experienced at KILN sessions enhanced that belief and further fed into their positive language ideology and resultant engagement with language, resulting in a "feedback loop" like Fast (2014) describes. Participants did not connect their languages with neoliberal concepts of the commodification of knowledge, nor connect it to economic incentives (Haque \& Patrick, 2015); rather, they understood the value of their language to be in the positive benefits and wisdom it holds for culture, spirituality, and identity and its usefulness in helping them to resist assimilation (Dementi-Leonard \& Gilmore, 2015; Haque \& Patrick, 2015). 


\section{Culture}

Language learning at KILN is inherently tied to cultural growth, as it offers access to both surface and deep aspects of culture (McIvor et al., 2009; Norton \& Toohey, 2011; Sarivaara et al., 2013). The participants had made a conscious choice to actively reclaim their cultures and languages; deepening knowledge led to more understanding, more community validation, and a desire for more knowledge (Fast, 2014). As numerous researchers have described, as participants learned together, they developed a common cultural identity, which increased group and intergenerational cultural transmission (Ball \& Mclvor, 2013; Baloy, 2011; De Souza \& Rymarz, 2007; McIvor et al., 2009; Norton \& Toohey, 2011). Many Indigenous people have associated shame with Indigenous culture-either shame at being Indigenous or shame at not being Indigenous enough—and positive participation in language learning activities helps to overcome that (Fast, 2014; King \& Hermes, 2014; Lawrence, 2004; Sherry-Kirk, 2014). The validation they experienced allowed them to bring their full selves to KILN, which helped them resist assimilation, celebrate the fullness of their heritage, and decolonize their concepts of Indigeneity and community belonging. For many participants, learning language and culture was spiritual, which enhanced the depth of their connections to one another, their Nations, their human and other-than-human relationships, their sacred teachings, and the land and allowed them to live their spirituality in meaningful ways (Fast, 2014; McIvor et al., 2009). The participants in this study were not learning about culture through language; they were actively participating in, internalizing, and creating culture through cultural ways of teaching and learning steeped in spirituality. 


\section{Identity}

The linguistic, cultural, and spiritual growth participants experienced informed their identities as urban Indigenous people. Many urban Indigenous people have complex identities that are informed by multiple factors (Baloy, 2011; Lawrence, 2004). Participation in language learning contributes to strong identity development that produces protective factors against some of the challenges urban Indigenous people face. These include the cultural shift of relocating to an urban area, mixed heritage, racism, the "collective trauma" of assimilation due to removal from language and culture; trauma reactions such as misuse of drugs and alcohol; and the misconception that urban Indigeneity is somehow less valid than rural, on-reserve, or northern Indigenous lifeways (Andersen, 2013; Baloy, 2011; De Souza \& Rymarz, 2007; Fast, 2014; Lawrence, 2004; Sarivaara et al., 2013; Sherry-Kirk, 2014; Shulist, 2018).

Participation in urban language revitalization contributes to healthy identity development in two ways. First, it allows participants to (re)connect to their heritage and Nation through shared language and culture. Participation in culture-based language learning allows participants to assert their Indigenous identity visibly and audibly, show pride in who they are, and overcome shame and assimilation (De Souza \& Rymarz, 2007; King \& Hermes, 2014). Second, participation in urban language revitalization enables participants to create an urban Indigenous identity that is reflective of their unique community; together, as with the participants in this study, they come to create new ways of being Indigenous (Andersen, 2013; Davis, 2015; Norton \& Toohey, 2011 Shulist 2018). As this study demonstrates, when participation is met with encouragement and acceptance, participants' pride in their identity 
grows even more (King \& Hermes, 2014). By asserting their identities and acknowledging the validity of others' identities, the participants challenged the misconception one cannot be urban and authentically Indigenous (De Souza \& Rymarz, 2007; Sherry-Kirk, 2014; Shulist, 2018). The element of shared territory and community diversity is important and unique for this study. Here, the urban identity that developed at KILN was shaped by the diversity of the community, which presented opportunities for everyone to learn, to compare languages, and to appreciate the diversity of Indigenous cultures and knowledges. That appreciation of cultural diversity led to greater appreciation of individual diversity, and so validation, acceptance, and trust were key components of KILN participants' experiences.

Andersen (2013) writes, "identity as being, essence, or sameness offers a sense of community and a point of solidarity, while offering the dignity of historical grounding. Conversely, identity as the process of becoming acknowledges the discontinuities and fragmentations marking our colonial experiences" (p. 49). Here, participants were engaged in processes of both being and becoming, in that they were living culture, creating a sense of community and solidarity, and (re)claiming knowledge systems that had been threatened by colonization and aggressive assimilation (Andersen, 2013). For some, that reclamation involved sharing knowledge they had always carried, or remembering knowledge that they had forgotten or been removed from. Others were experiencing it for the first time. For many of the participants, regardless of the knowledge they carried when they arrived at the KILN sessions, learning was a process of owning their Indigeneity and becoming stronger in their identities as members of their Nations and the urban community. 


\section{Conclusion}

Urban language revitalization is vital to the overall movement of Indigenous language revitalization. It ensures that urban Indigenous people, who are the majority of the Indigenous population, have access to their languages. It expands speaker numbers, domains of language use, urban Indigenous presence, and understanding of the value of Indigenous languages. That enables urban Indigenous communities to develop positive language ideologies; in this case, participants understood that their languages belonged in the city, that the diversity of their community was additive rather than divisive, that their languages had intrinsic value, and that they as individuals had the ability to learn their languages. However, urban language revitalization is about much more than language. When the approach is rooted in Indigenous cultures and spiritualities, it has the potential to make a difference in participants' understanding of themselves and their urban Indigenous community. In this case, participants recognized the importance of local Anishinaabe and Haudenosaunee teachings to local urban identity. They also saw diversity as a unique and important part of their community. By participating in language revitalization, participants were both living their Indigenous cultures and creating new ways of understanding what it means to be a part of their unique urban community. In short, urban language revitalization matters. With ongoing Indigenous urbanization, leading initiatives like KILN will be increasingly central to the survival of our languages and cultures and the development of new, unique, and beautiful ways to be Indigenous. 


\section{About the Author}

Dr. Lindsay Morcom is a Canada Research Chair in Language Revitalization and Decolonizing Education at Queen's University. She holds a D.Phil. from Oxford University and is a Rhodes Scholar. She belongs to Ardoch Algonquin First Nation and is also a proud member of the Kingston urban Indigenous community. She carries Algonquin, French Canadian, and Black Sea German heritage and embraces the unique responsibilities her heritage presents for reconciliation.

\section{References}

Alderville First Nation. (2016). History. Alderville First Nation. https://alderville.ca/alderville-first-nation/history

Algonquins of Ontario (2013). Overview of treaty negotiations. Algonquins of Ontario. https://www.tanakiwin.com/our-treaty-negotiations/overview-of-treatynegotiations/

Ardoch Algonquin First Nation. (n.d.) Getting in touch. Ardoch Algonquin First Nation. http://www.aafna.ca/contact-us

Andersen, C. (2013). Urban Aboriginality as a distinctive identity, in twelve parts. In E. Peters \& C. Andersen (Eds.). Indigenous in the city: Contemporary identities and cultural innovation (pp.1-21). UBC Press.

Assembly of First Nations [AFN]. (2010). First Nations control of First Nations education. https://www.afn.ca/uploads/files/education/3. 2010 july afn first nations control of first nations education final eng.pdf

Ball, J., \& McIvor, O. (2013). Canada's big chill: Indigenous languages in education. In C. Benson \& K. Kosonen (Eds.), Languages in comparative education: Inclusive teaching and learning in non-dominant languages and cultures. (pp. 19-38). Sense Publishers.

Baloy, N. J. K. (2011). “We can't feel our language”: Making places in the city for Aboriginal language revitalization. The American Indian Quarterly, 35(4), 515-548.

Battiste, M. (2013). Decolonizing education: Nourishing the learning spirit. Purich.

Chao, X. \& Waller, R. (2017). Urban Indigenous bilingualism: An "environmental allergy?" Urban Education. https://doi.org/10.1177/0042085917727572

Congress of Aboriginal Peoples [CAP]. (2018). Final submission to the inquiry into missing and murdered Indigenous women and girls. https://www.mmiwg-ffada.ca/wpcontent/uploads/2019/02/CAP-Final-Written-Submission.pdf 
Davis, J. L. (2015). Language affiliation and ethnolinguistic identity in Chickasaw language revitalization. Language \& Communication. http://dx.doi.org/10.1016/j.langcom.2015.04.005

De Souza, M. \& Rymarz, R. (2007). The role of cultural and spiritual expressions in affirming a sense of self, place, and purpose among young urban, Indigenous Australians. International Journal of Children's Spirituality, 12(3), 277-288.

Dementi-Leonard, B., \& Gilmore, P. (1999). Language revitalization and identity in social context: A community-based Athabascan language preservation project in western interior Alaska. Anthropology \& Education Quarterly, 30(1), 37-55.

Fast, E. (2014). Exploring the role of culture among urban Indigenous youth in Montreal. [Doctoral dissertation, McGill University]. Researchgate. https://doi.org/10.13140/2.1.4226.3361

Haque, E. \& Patrick, D. (2015). Indigenous languages and the racial hierarchization of language policy in Canada. Journal of Multilingual and Multicultural Development, 36(1), 27-41. https://doi.org/10.1080/01434632.2014.892499

Inuit Tapiriit Kanatami [ITK]. (2017). (re)Visioning success in Inuit education: A report of the 2017 Inuit education forum. https://www.itk.ca/wpcontent/uploads/2017/10/inuitreport-web.pdf

Jewell, E. M. (2016). Social exposure and perceptions of language importance in Canada's urban Indigenous peoples. Aboriginal Policy Studies, 5(2), 99-113.

King, K. A., \& Hermes, M. (2014). Why is this so hard?: Ideologies of endangerment, passive language learning approaches, and Ojibwe in the United States. Journal of Language, Identity, and Education, 13(4), 268-282. https://doi.org/10.1080/15348458.2014.939029

Kingston Health Sciences Centre. (2021). Ininew patient services. Kingston Health Sciences Centre. https://kingstonhsc.ca/programs-and-departments/ininew-patient-services

Kingston Indigenous Languages Nest [KILN]. (2019). About the community. Kingston Indigenous Languages Nest. https://kingstonIndigenouslanguage.ca/resources/about-the-community/

Lawrence, B. (2004). "Real" Indians and others: Mixed-blood urban Native peoples and Indigenous nationhood. UBC Press.

Luning, R. J. I., \& Yamauchi, L. A. (2010). The influences of Indigenous heritage language education on students and families in a Hawaiian language immersion program. Heritage Language Journal, 7(2), 46-75. 
McIvor, O., Napoleon, A., \& Dickie, K. M. (2009). Language and culture as protective factors for at-risk communities. Journal of Aboriginal Health, 5(1), 6-25.

Métis Nation of Ontario. (2021). Community councils map. Métis Nation of Ontario. https://www.metisnation.org/community-councils/community-councils-map/

Morgan, B. \& Clarke, M. (2011). Identity in second language teaching and learning. In E. Hinkel (Ed.), Handbook of research in second language teaching and learning. (pp. 817-836). Routledge.

Norton, B., and Toohey, K. (2011). Identity, language learning, and social change. Language Teaching, 44(4), 412-446.

Osborne, B. S. (2019). Kingston. The Canadian encyclopedia. https://www.thecanadianencyclopedia.ca/en/article/kingston

Peters, E., \& Andersen, C. (2013). Introduction. In E. Peters \& C. Andersen (Eds.). Indigenous in the city: Contemporary identities and cultural innovation (pp. 1-21). UBC Press.

Pitawanakwat, B. T. (2009). Anishinaabemodaa pane oodenang: A qualitative study of Anishinaabe language revitalization as self-determination in Manitoba and Ontario. [Doctoral dissertation, University of Victoria]. UVicSpace. http://hdl.handle.net/1828/1707

Sarivaara, E., Uusiautti, S. \& Määttä, K. (2013). How to revitalize an Indigenous language? Adults' experiences of the revitalization of the Sámi language. Cross-Cultural Communication, 9(1) 13-21. http://dx.doi.org/10.3968/i.ccc.1923670020130901.2121

Sherry-Kirk, L. (2014). Indigenous language reclamation - the learners perspective. [Master's thesis, Brock University]. Brock University M.A. Social Justice and Equity Studies. http://hdl.handle.net/10464/5270

Shulist, S. (2017). A tale of two languages: Indigenous language education and ideologies in an urban context. Revista Linguística/Revista do Programa de Pós-Graduação em Linguística da Universidade Federal do Rio de Janeiro, 13(1), 168-187.

Shulist, S. (2018). Transforming indigeneity: Urbanization and language revitalization in the Brazilian Amazon. University of Toronto Press.

Statistics Canada. (2018, August 9). Census profile, 2016 census: Kingston [population centre], Ontario and Ontario [province]. https://www12.statcan.gc.ca/censusrecensement $/ 2016 / \mathrm{dp}$ $\mathrm{pd} / \mathrm{prof} /$ details $/$ page.cfm?Lang=E $\&$ Geo $1=$ POPC \&Code $1=0415 \& G e o 2=$ PR \&Code $2=3$ $\underline{5 \& \text { Data }=\text { Count } \& \text { SearchText=Kingston } \& \text { SearchType=Begins } \& \text { SearchPR }=01 \& B 1=\text { All }}$ 
Statistics Canada. (2019, April 3). The Aboriginal languages of First Nations people, Métis and Inuit. https://www12.statcan.gc.ca/census-recensement/2016/as-sa/98-200$\mathrm{x} / 2016022 / 98-200-\mathrm{x} 2016022$-eng.cfm

Statistics Canada. (2021, February 12). Population estimates, July 1, by census metropolitan area and census agglomeration, 2016 boundaries.

https://www150.statcan.gc.ca/t1/tbl1/en/tv.action?pid=1710013501 